\title{
The Influence of the Application of Balanced Scorecard on the Financial Performance of Enterprises
}

\author{
Xiaoye Fang ${ }^{*}$ and Xiaoting Qu
}

Beijing Jiaotong University

*Corresponding author.Email:20120689@bjtu.edu.cn

\begin{abstract}
As Chinese enterprises attach more importance to the management ability, more and more companies expect to optimize the management process by using the balanced scorecard, a management tool. This paper analyzes the situation and effect of applying Balanced Scorecard (BSC) in the annual reports disclosed by a listed real estate Company A from 2001 to 2019, reflects its financial performance with the changes of relevant financial indicators, and draws the conclusion that the financial performance of company A has been enhanced after applying BSC,and puts forward ssuggestions for other enterprises using the balanced scorecard, in order to make the BSC in enterprise strategic management take effect.
\end{abstract}

Keywords: Balanced Scorecard, Performance management, Financial performance.

\section{INTRODUCTION}

The balanced scorecard theory has been developed in foreign countries for 20 years, and many large enterprises around the world have realized the positive role of BSC and applied it. According to the survey of Gartner (2002), $60 \%$ of the world's top 1000 enterprises have been using this management tool [1]. However, Chinese enterprises only introduced BSC in the 1990s , and we study the application of BSC in listed companies and its impact on financial performance, which is conducive to promoting the implementation of BSC in Chinese enterprises and improving the management ability of enterprises.

\section{RESEARCH STATUS OF BALANCED SCORECARD THEORY SYSTEM}

\subsection{Balanced Scorecard Theory System}

BSC is different from the traditional performance assessment system with financial indicators as the core. In addition to the financial perspective, BSC also introduces other non-financial indicators: external customer, internal process and learning and growth. It is a set of brand-new and comprehensive strategic performance management tools that comprehensively evaluates the business performance of enterprises and employees from the perspective of strategy and sets up four levels of indicators according to enterprise strategy. Because it not only plays the role of performance assessment, but also uses relevant indicators to measure employee performance to convey to employees the driving factors of enterprise success, so as to carry forward the enterprise culture and unite employees to achieve long-term goals.

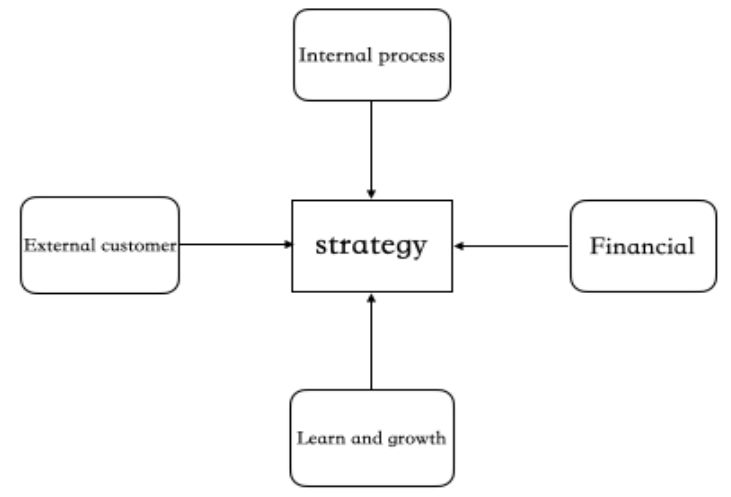

Figure 1 Balanced scorecard theory system.

\subsection{Research Overview}

Theoretical research on BSC originated in foreign countries. Kaplan and Norton published a summary of the remarkable achievements of BSC in enterprise application in 1992 [2], which opened the prelude of academic research on BSC. Hoque (2014) pointed out 
the possible achievements in BSC research and a series of future research opportunities [3], which points out the development direction for the research after BSC. Later, many scholars took part in the research of BSC and integrated BSC with other management tools [4], such as linking it with corporate culture [5] and strategic management [6]. Reinhard E. Kounz et al. obtained the application steps of BSC in 2016, that is, to propose the target, decompose the target, design THE BSC index, and provide feedback on the completion of the index, which greatly enriched the theoretical system of BSC [7].

Theoretical research in China began in 2003 with the translation of Professor Hu Yuming's Practical Guide to Balanced Scorecard, and many relevant foreign works were gradually translated and published later. In 2003, Yuling Sun and Berman introduced case companies to analyze the differences between BSC and the traditional performance management model and its advantages, which aroused great response from domestic management academia [8]. Subsequently, Chinese scholars began to study BSC one after another. On the one hand, some scholars combined BSC with other management tools and indicators such as Activity-Based Costing [9], Economic Added Value [10], and Comprehensive Budget Management [11], which enriched the connotation of BSC. On the other hand, the performance evaluation system with $\mathrm{BSC}$ as the main body can be improved by introducing case enterprises. In 2008, Shen Lei analyzed some problems arising from the application of BSC as a management tool in commercial banks and put forward suggestions [12]. In 2018, Liu Jiaxin studied the performance evaluation system of H company and summarized its defects, and then set up the index system of BSC for H company [13].

BSC's basic theory, covering itself, is combined with its specific application in practice development far beyond the theoretical framework of BSC theory system and the existing research focused on the improvement of the BSC system, but the impact on financial performance, and the research is blank, and clear its impact on financial performance can improve enterprise application of BSC's enthusiasm, promote the development of BSC.

\section{APPLICATION OF BSC IN A COMPANY}

Through the use of BSC, Company A has achieved its own strategic development, the occupation of market and the improvement of management ability. Therefore, this paper collates the annual reports disclosed by Company A from 2001 to 2019 when BSC was applied, and analyzes its strategies in corporate finance, customers, internal and process, learning and growth, as well as the benefits gained by the company after BSC was applied in 2001.

\subsection{Financial}

After company A went public in 1991, in the face of the instability of the stock market, in order to maintain its strong ability to raise funds in the stock market, its financial goal is to "maximize shareholder returns," and a "good" financial data can show to the world the longterm development ability of the enterprise, and it is also one of the earliest Chinese company to define economic profits as the one of the main evaluation index. Company A will also adjust financial policies and financial indicators of BSC according to the specific conditions of the year. For example, in 2005, Company A took "cash is king" as its sales strategy and reduced cash expenditure. This policy can increase asset turnover rate and asset turnover. In 2010, the economic profit bonus system was implemented, making the economic profit index and the pay of managers linked.

\subsection{External Customer}

Throughout the annual report of Company A in the past 19 years, it disclosed the important management measures at the customer level every year. In 2001, in order to improve the market competitiveness from the perspective of customers, Company A proposed the activity of "Customer Smile Year" to its employees, conveying the message that customers come first. In 2003, the management structure of A company's customer service system based on the improvement of customer satisfaction and loyalty has been preliminarily formed.Company A in 2006 began to implement the strategy of customer segmentation.In 2013, the company began to invite customers to participate in the real estate administration of quality supervision, and promote derivative services customer need, the customer satisfaction has improved in 2012 [14]. In 2018, company A aims to promote product upgrades, to customer oriented, the organization carried out the activity we are customers, encouraging and inspiring the staff from the perspective of customer to think about how to solve the key points,so as to promote the product updating.

\subsection{Internal Process}

Focus on improving the business management process. In 2003, it strengthened the control of key processes and the management of suppliers, and initially established the three-level procurement system of group centralized, regional and fixed-point procurement. In 2017, digital technology was introduced to participate in project management on the basis of the original operation. In order to improve the accuracy of construction drawings, BIM building information technology was promoted in the enterprise. Meanwhile, BIM 5D project management platform was developed for the real-time collection of data generated during 
construction. In 2018, in order to optimize the office platform, a smart operation and maintenance system was piloted to improve employees' office efficiency [15]

\subsection{Learning and Growth}

Company A believes that human resources are the most precious capital and has been seeking, cultivating and retaining excellent employees. The company first introduced BSC system in order to better carry out human resource management. Since 2003, it has trained employees on professional skills and management level.Every year, it organizes company-wide "goals and actions" special activities to help employees understand the strategic goals of the enterprise, and set up job descriptions to help employees understand their responsibilities. When recruiting, Company A adheres to the principle of "moral quality first" in selecting employees. In terms of staff training, the company organizes staff training by the human resources department every year and holds professional examinations regularly. In 2013, the company established a management school, aiming to promote cross-border learning among enterprises [14]. In the past 18 years, the company cut down the organizational level, improved the employee incentive mechanism, and enhanced the employee's work vitality [15]. In terms of employee retention, Company A disclosed in its 2008 annual report that it combined BSC evaluation results with employees' compensation, so that employees' efforts could be reflected in their compensation to improve their work enthusiasm. At this level, Company A also introduced employees' physique as an indicator, with the purpose of encouraging employees to attach importance to physical health and actively adhere to exercise.

\section{FINANCIAL PERFORMANCE ANALYSIS}

The author makes statistics on some financial indicators of A company from 2000 to 2019, and lists the total profit and its growth rate, total assets and its growth rate in the year 2018 and 2019 before the application of BSC system, to reflect the changes of enterprise development ability before and after the application of BSC system. The return on equity calculated by the weighted average method and its growth rate reflect the change of its profitability.

Table 1. A Company's financial position

\begin{tabular}{|c|c|c|c|c|c|c|c|c|c|}
\hline & Year & 2000 & 2001 & 2008 & 2009 & 2013 & 2017 & 2018 & 2019 \\
\hline \multirow{2}{*}{$\begin{array}{c}\text { development } \\
\text { ability }\end{array}$} & $\begin{array}{c}\text { Total profit } \\
\text { (ten thousand yuan) }\end{array}$ & 380333 & 50185 & 197618 & 861743 & 2429101 & 5114195 & 6746020 & 7653929 \\
\cline { 2 - 9 } & $\begin{array}{c}\text { asset-liability ratio } \\
\text { total assets } \\
\text { (ten thousand yuan) }\end{array}$ & $47.58 \%$ & $51.78 \%$ & $60.98 \%$ & $67.00 \%$ & $78.00 \%$ & $83.98 \%$ & $84.59 \%$ & $84.36 \%$ \\
\hline \multirow{2}{*}{ profitability } & $\begin{array}{c}\text { Monthly weighted } \\
\text { average return on } \\
\text { equity }\end{array}$ & $10.65 \%$ & $12.21 \%$ & $16.25 \%$ & $15.37 \%$ & $21.54 \%$ & $22.80 \%$ & $23.24 \%$ & $22.47 \%$ \\
\hline
\end{tabular}

Table 2. The growth of corporate financial indicators

\begin{tabular}{|c|c|c|c|c|c|c|c|c|c|}
\hline & Year & 2000 & 2001 & 2008 & 2009 & 2013 & 2017 & 2018 & 2019 \\
\hline \multirow{2}{*}{$\begin{array}{c}\text { development } \\
\text { ability }\end{array}$} & $\begin{array}{c}\text { Gross profit growth } \\
\text { rate }\end{array}$ & - & $31.95 \%$ & $293.78 \%$ & $336.06 \%$ & $181.88 \%$ & $110.54 \%$ & $31.91 \%$ & $13.46 \%$ \\
\cline { 2 - 9 } & $\begin{array}{c}\text { Growth rate of assets liabilities } \\
\text { Total Assets Growth } \\
\text { Rate }\end{array}$ & - & $8.83 \%$ & $17.77 \%$ & $9.87 \%$ & $16.42 \%$ & $7.67 \%$ & $0.73 \%$ & $-0.23 \%$ \\
\hline \multirow{2}{*}{ profitability } & $\begin{array}{c}\text { Growth rate of return } \\
\text { on equity }\end{array}$ & - & $14.65 \%$ & $33.09 \%$ & $-5.42 \%$ & $40.14 \%$ & $5.85 \%$ & $1.93 \%$ & $-0.77 \%$ \\
\hline
\end{tabular}


As can be seen from Table 1 and Table 2, the total profit reflecting the sustained growth capacity of enterprise profits increased by $31.95 \%$ year-on-year at the end of the year when BSC was applied.

In the first five years of BSC application, the total profit increased by nearly three times, and more than three times in the second five years. In the third five years, the growth rate slowed down, but it was still as high as 1.8 times, and in the fourth five years, it increased by about one time, and then compared to 2017 it increased by $31.91 \%$ in 2018 . The ability of assets and liabilities reflecting the solvency of enterprises presents an overall trend of growth. In the second year of the application of BSC, the total asset growth rate increased by $16.11 \%$, and then more than doubled in the first five years, more than fivefold in the second five years, more than doubled and more than doubled in the third and fourth five years, respectively. In 2018, it increased by $31.17 \%$ compared to 2017 , and in 2019 , it increased by $13.17 \%$.

The rising trend of return on equity, which reflects corporate profitability, is slow but still rising, with the largest increase in the year BSC was applied. In the second five years there was a decline, in the third five years there was a rapid recovery and a significant increase, and then there was a slowdown in the growth rate, but it was a growth trend. This indicates that Company A has achieved very good results in the application of BSC in business performance. And the reason why the level of return on net assets in the third five years of rapid growth may be that company A introduced EP bonus system in 2010, and used the business partner system to link the financial indicators with the bonus level of senior managers, so as to realize the risk-sharing and income-sharing of the enterprise, which made the company's managers pay more attention to the business status and performance level of the enterprise.

\section{CONCLUSION AND RECOMMENDATION}

From the above analysis, it can be seen that the financial performance of Company A, represented by its profitability and development ability, has been growing for most of the time in the past ten years after BSC was applied. In the first decade, when BSC was just applied by A company, its financial performance showed A doubling trend of growth, especially when new incentive policies were introduced, its financial performance would be significantly improved. With the increasingly close combination of BSC and corporate management, the growth rate of corporate performance brought by BSC began to slow down gradually, but it was an overall trend of growth.
Therefore, the BSC financial performance have a positive impact on the company, then from the application of the company, the following suggestions and experiences can be summarized from the application of Company A:

\subsection{Listed Companies Should Maintain the Dominant Position of Financial Indicators}

Although BSC focuses on non-financial indicators, the original intention of BSC is to improve the management level and profitability of enterprises in order to maximize the value of enterprises. Therefore, it is reasonable for listed companies to attach importance to financial indicators. However, in order to realize their healthy and long-term development, it is also necessary to pay attention to non-financial indicators, because the good performance of non-financial indicators can lay a foundation for the excellent performance of financial indicators. For listed companies, the most appropriate decision is to combine financial indicators and nonfinancial indicators in the application of BSC to achieve mutual success. Among them, the weight of financial indicators should be set slightly higher than nonfinancial indicators to reflect the importance of financial indicators, so as to achieve long-term, healthy and sustainable development of enterprises.

\subsection{Introduce Information System and Establish Effective Communication Mechanism}

In all the processes of BSC, effective discussion and communication is the most important element, the effective means and the most basic guarantee for the realization of enterprise strategic planning. Kaplan mentioned in the interview that "no matter what kind of strategic structure the enterprise is using, if the strategy is to be effectively implemented, it must be transformed and communicated among all business departments and employees" [16]. For enterprises implementing BSC, in order to run BSC healthily, it is necessary to start from the two aspects of promoting the perfection of communication mechanism and BSC informatization. With the rapid development of technology, companies can now introduce information systems to establish communication mechanisms. For example, a company shared resource database can be established to release various announcements, department employee information and company business completion, including the application and requirements of BSC. BSC performance evaluation results can be published to all employees at the end of the year, which can encourage employees to take BSC seriously and improve work efficiency. Combining BSC with information technology can also realize the efficient utilization of BSC. The informationized BSC system established by the Central Hospital of Karamay city in 
Xinjiang has comprehensively improved the operation efficiency and management level of the hospital [17].

\subsection{Link BSC to Pay System}

If the application of BSC does not interact with the actual interests of employees, then employees will ignore the role of $\mathrm{BSC}$, and ultimately fail to produce the desired results. In a survey of 214 companies, William M. Mercer found that $88 \%$ of them have widely applied the non-financial assessment method contained in BSC to employee bonus plan [18]. When Company A applied BSC, the evaluation result was linked to the bonus amount of employees, which resulted in a high increase of Return On Equity

Therefore, when applying BSC to other listed companies, BSC indicators should be combined with the actual personal interests of employees first. The human resources department sets performance bonus subject under the salary system, and at the end of each year, all departments calculate results of BSC evaluation and give extra rewards and commendations to employees with higher scores, which can make staff in the usual work focus on BSC indicators, and rely on BSC indicators on the working height to their request, help enterprise in the aspect of employee accelerate the process of strategic goals.

\section{REFERENCES}

[1] Liang Yingyu. Research on the application of BSC in Corporate Performance Evaluation in China [D]. Soochow University, 2008.

[2] S. Robert. D.P.Kaplan.Norton,The balanced Scorecard-Measures That Drive Performance.Harvard BusinessReview.Jan/Feb 1992,Vol70,issue 1,71-79.

[3] Z.Hoque.20 years of studies on the balanced scorecard:Trends,accomplishments,gaps and opportunities for future research[J].The British Accounting Review,2014(1):33 59.

[4] R.S.Kaplan, D.P.Norton, Strategy maps: Converting intangible assets into tangible outcomes [M].Boston:Harvard Business School Press,2004:1-324.

[5] Arash Shahin,Javad Shabni Naftchali,Javad Khazaei Pool.Developing a model for the influence of perceived organizational climate on organizational citizenship behaviour and organization performance based on balanced score
card[J].International Journal of Productivity and Performance Management,2014,633:542-578.

[6] Nicholas John Wake.The use of the balanced scorecard to measure knowledge work [J].International Journal of Productivity and Performance Management, 2015, 64(4):590-602.

[7] Reinhard E.Kunz,Johannes Siebert,Joschka Miitterlein.Combining Value-focused Thinking and Balanced Scorecard to Improve Decisionmaking in Strategic Management [J].J. Multi-Crit. Decis. Anal, 2016, (3):5-6.

[8] Sun Yongling.Irv Beiman.BSC Strategic Guidance [J]. Harvard Business Review.2003, (7):23-24.

[9] Wang Fenting, Liu Qunling, Qiao Lili, Song Zhenhui. Extended BSC System based on activitybased Costing $[\mathrm{J}]$. China Management Informatization, 2012(5):78-83

[10] Yao Lihui, Kang Jinjun. Research on performance Evaluation System of Management Equity Incentive [J]. CPA, 2018(21):45-46.

[11] Jia Xiaoyan. Research on enterprise Comprehensive Budget Management based on BSC [J]. CPA, 2019(05):18-19.

[12] Shen Lei. Application of BSC in Performance Management of Commercial Banks in China: Problems and Countermeasures [J]. New Finance. 2008(9):34-37

[13] Liu Jiaxin. Research on Performance Evaluation of H Company based on BSC [D]. Harbin University of Commerce, 2018.

[14] China Vanke Co.,Ltd. (2013). Annual Report [R]. Shenzhen: China Vanke Co.,Ltd., 2014.

[15] China Vanke Co.,Ltd. (2018). Annual Report [R]. Shenzhen: China Vanke Co.,Ltd., 2019

[16] Ding Yougang, Li Bilong, Zhang Shan.Kaplan Interview Series 8 [J]. Friends of Accounting,2011(04):128.

[17] Dong Lin, Peng Yuming, Yang Xiaoyan. Implementation and application of comprehensive information-based BSC evaluation system [J]. China digital medicine, 2015, 10(11):20-22.

[18] Luo Hongzhu, Kaixi. Research on strategic Business Performance Evaluation of enterprises [J]. Productivity Research, 2002(1). 